\title{
BIMODAL NANOINDENTATION RESPONSE OF THE (001) FACE IN CRYSTALLINE SODIUM SACCHARIN DIHYDRATE •
}

\author{
Manish Kumar Mishra ${ }^{1}$, Upadrasta Ramamurty ${ }^{2,3, *}$, Gautam R. Desiraju ${ }^{1, *}$ \\ ${ }^{1}$ Solid State and Structural Chemistry Unit, Indian Institute of Science, Bangalore 560 012, India \\ ${ }^{2}$ Department of Materials Engineering, Indian Institute of Science, Bangalore 560012 , India \\ ${ }^{3}$ Center of Excellence for Advanced Materials Research, King Abdulaziz University, Jeddah 21589, \\ Saudi Arabia \\ *desiraju@sscu.iisc.ernet.in; ramu@materials.iisc.ernet.in
}

\begin{abstract}
The nanoindentation response of the (001) face of sodium saccharin dihydrate is examined. The structure can be demarcated into regular and irregular regions or domains. The regular domains have solid-like and the irregular ones have liquid-like characteristics. Therefore, these domains impart a microstructure to the crystal. The indent face (001) is prominently developed in this crystal and unambiguously presents the regular and irregular regions to nanoindention. Average values of elastic modulus and hardness show a distinct bimodal mechanical response. Such a response has been observed in the case of intergrown polymorphs of aspirin and felodipine. We examine two possible reasons as to why the responses could be for bimodal in this crystal. The first possibility could be that the two domains correspond to regions of the original dihydrate and a lower hydrate that is obtained by the loss of some water. The second possibility could be that these responses correspond to regular and irregular regions in the structure. Nanoindentation is a very useful technique in the characterization of molecular solids, as a complementary technique to X-ray crystallography, because it samples different length scales.
\end{abstract}

Keywords: crystal engineering; microstructure; hydrate; saccharin; nanoindentation

\section{БИМОДАЛЕН НАНОВДЛАБНУВАЧКИ ОДГОВОР НА ПЛОСКАТА (001) ВО КРИСТАЛНИОТ НАТРИУМСАХАРИНАТ ДИХИДРАТ}

Изучуван е нановдлабнувачкиот одговор на плоската (001) во кристалниот натриумсахаринат дихидрат. Структурата може да се разграничи преку регуларни и ирегуларни подрачја или домени. Регуларните домени имаат карактеристики на цврста состојба, а оние ирегуларните на течна состојба. Затоа овие домени ги прават кристалите микроструктурни. Плоската (001) во овој кристал е посебно развиена и недвосмислено ги презентира регуларните и ирегуларните региони на нановдлабнувањето. Средните вредности на еластичниот модул и на тврдоста покажуваат различен бимодален механички одговор. Таков одговор е забележан во случајот на сраснати полиморфи на аспирин и фелодипин. Изучени се двете можни причини зошто одговорите за овој кристал би биле бимодални. Првата можност би можела да биде дека двата домена одговараат на подрачјата на оригиналниот дихидрат и на понискиот хидрат добиен како резултат на губење на дел од водата. Втората можност би можела да биде дека овие одговори соодветствуваат на регуларните и ирегуларните подрачја во структурата. Нановдлабнувањето е многу корисна техника за карактеризирање на молекуларни цврсти супстанци, како комплементарна техника на рендгенската кристалографија, бидејќ таа опфаќа различни должински скали.

Клучни зборови: кристално инжинерство; микроструктура; хидрат; сахарин; нановдлабнување

\footnotetext{
- Dedicated to Academician Gligor Jovanovski on the occasion of his $70^{\text {th }}$ birthday.
} 


\section{INTRODUCTION}

Nanoindentation is a technique that can be employed to quantitatively measure the mechanical properties of relatively small volumes of materials [1-12]. In the crystal engineering context [13-16], this particular feature has been utilized in the recent past to establish structure-property correlations for a variety of molecular solids; one such aspect is in the study of intergrowth polymorphism in active pharmaceutical ingredients (APIs) such as aspirin [3] and felodipine [8]. The higher spatial resolution of the nanoindentation technique, vis-àvis X-ray diffraction (XRD), is especially relevant in this context. Since the recorded load, $P$, versus the depth of penetration of the indenter tip, $h$, curves is sensitive to the crystal packing and intermolecular interactions, different polymorphs give rise to distinctly different $P-h$ responses. Thus, it is possible to use the nanoindentation measurements as signature responses reflecting the structure of the material underneath, and in turn, to study the "microstructure", if any, that exists within a single crystal of an organic compound [3, 8]. In the present paper, we extend this approach to examine sodium saccharin "dihydrate", more accurately represented as $\mathrm{Na}(\mathrm{sac}) .1 .875 \mathrm{H}_{2} \mathrm{O}$, which is the most common form of saccharin [17-18].

The crystal structure of this compound is very complex and is shown in Figure 1. The compound takes the monoclinic space group $P 2_{1} / \mathrm{c}$ and $Z=4$ with the following unit cell parameters: $a=$ $18.5918(11), b=28.3628(16), c=29.0562(16) \AA$, $\beta=93.5940(10)^{\circ}$. The number of species, 362 atoms of which 238 are non-H atoms, in the crystallographic asymmetric unit, make the unit cell very large $\left(V=15614 \AA^{3}\right)$. There are $64 \mathrm{Na}^{+}$cations, 64 $\mathrm{sac}^{-}$anions and 120 water molecules in the unit cell. It is of interest to note that this dihydrate was originally characterized by Jovanovski and Kamenar [19-20]. The crystal structure was determined simultaneously and independently by Naumov et al. [21] and by Banerjee et al. [22] in 2005. Banerjee et al. [22] have described this crystal structure in terms of an incipient crystal nucleus, and it is therefore of fundamental mechanistic interest. The structure can be demarcated into "regular" and "irregular" regions or domains. In the regular domains, the saccharin anions ( $\mathrm{sac}^{-}$) are nearly parallel and stacked with an average plane perpendicular distance of $3.69 \AA$ along the b-axis. The $\mathrm{Na}^{+}$ions are hexa-coordinated (mean $\mathrm{Na}^{+} \ldots \mathrm{O}$ distance $2.39 \AA$ ) with water whereas $\mathrm{sac}^{-}$and the water molecules are held efficiently with strong $\mathrm{O}_{-}$ $\mathrm{H} \cdots \mathrm{N}^{-}$hydrogen bonds $(\mathrm{D}=2.85 \AA$ and $\left.\theta=165.8^{\circ}\right)$. In the irregular domains, $\mathrm{sac}^{-}$anions and $\mathrm{Na}^{+}$cations (some of which are not necessarily hexa-coordinated but rather penta- and heptacoordinated) and water are both positionally and orientationally disordered. We had noted previously that there is a significant amount of variability in the structure of these irregular regions, from crystal to crystal. These regular and irregular domains impart a "microstructure" to the crystal, so that the regular domains have "solid-like" and the irregular ones have "liquid-like" characteristics. If this is indeed the case, could one study these domains using the nanoindentation technique? We seek the answer to this question in this paper. In this context, it is worth noting that Kiran et al. [2] examined the nanoindentation response of the (011) and (101) facets of crystals of the title compound and demonstrated fluid flow due to water molecules oozing out during indentation on the (011) face. Kiran et al. [2] examined these faces because they were interested in the mechanism of solvent loss in this compound. Because of the marked anisotropy in the crystal packing, it was anticipated that the mechanical responses on other faces would be quite different. In the present paper, we examine the nanoindentation response on the (001) face, a prominently developed face of the crystal that distinctly presents the regular and irregular regions to nanoindention.

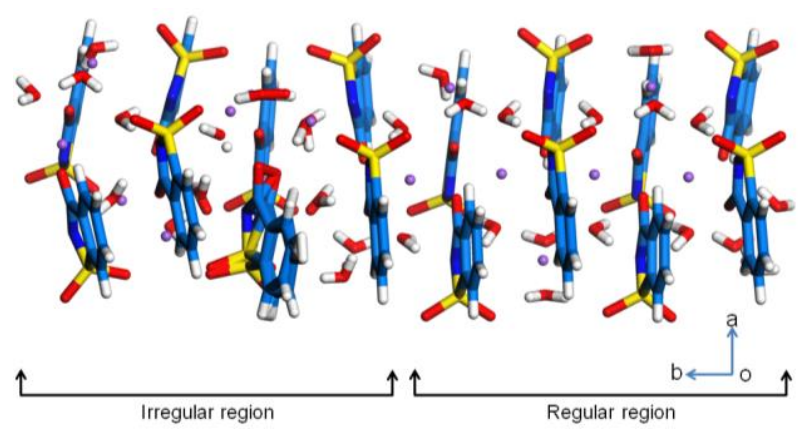

Fig. 1. Asymmetric unit of sodium saccharin dihydrate. The irregular regions are on the left side and the regular regions on the right side. Nanoindentation is performed on the

(001) face in other words down the plane of the page.

\section{EXPERIMENTAL}

Commercially available sodium saccharinate dihydrate (Loba Chemie India Ltd.) was used for crystallization. Large single crystals (typical size: 2 $\mathrm{cm} \times 1 \mathrm{~cm} \times 0.5 \mathrm{~mm}$ ) were grown by slow evaporation of a saturated solution of water at room temperature for a week. The harvested crystals were washed with paraffin oil to remove any small crystallites that might have stuck to their surface. Sub- 
sequently, they were firmly mounted on a metallic stud using cyanoacrylate glue for the nanoindentation experiments. These experiments were performed on the (001) faces with the Triboindenter of Hysitron, Minneapolis, USA, equipped with a three-sided pyramidal Berkovich tip (tip radius of $\sim 100 \mathrm{~nm}$ ). The loading and unloading rates were $0.7 \mathrm{mN} / \mathrm{s}$, hold time at the peak load of $7 \mathrm{mN}$ was $30 \mathrm{~s}$, and resolution of $P$ and $h$ were $1 \mathrm{nN}$ and 0.2 nm, respectively. The $P-h$ curves were analyzed using the standard Oliver-Pharr method [23-24] to extract the elastic modulus, $E$, and hardness, $H$. Around 45 indentations were performed on about 4 crystals.

\section{RESULTS AND DISCUSSION}

Representative $P$ - $h$ curves obtained on the (001) faces are displayed in Figure 2(a). Two measured responses partition themselves into two distinct sets, which are labeled as $\mathbf{1}$ and $\mathbf{2}$ in Figure 2 a. Average values of elastic modulus $(E)$ and hardness $(H)$, estimated for these two different sets of data are listed in Table 1, from which it can be noticed that $E$ and $H$ values estimated for group 1 's responses are higher, by more than $50 \%$, than the respective values of group 2. This is further illustrated by plotting $E v s$. $H$, which are estimated from each individual $P$ - $h$ response. A distinct bimodal response is apparent. Such a response has been observed previously by us in the case of intergrown polymorphs of aspirin [3] and felodipine [8]. Data reported by Kiran et al. [2] on (011) and (101) faces are also displayed in Table 1 . A comparison of the $E$ and $H$ values obtained on different faces of asgrown crystals clearly shows that the (001) facet of the hydrate crystal is considerably stiffer and harder than the other two facets.

While the experimental bimodal response confirms the possible existence of two structurally distinct domains in the title dihydrate, the origins and length scales of these structural heterogeneities re- quire detailed discussion. We examine two possible reasons for this. Sodium saccharin dihydrate belongs to a complex landscape [25-29] of hydrated and anhydrous forms and readily and nearly spontaneously converted into a lower hydrate, $\mathrm{Na}_{3}(\mathrm{sac})_{3} \cdot 2 \mathrm{H}_{2} \mathrm{O}$.

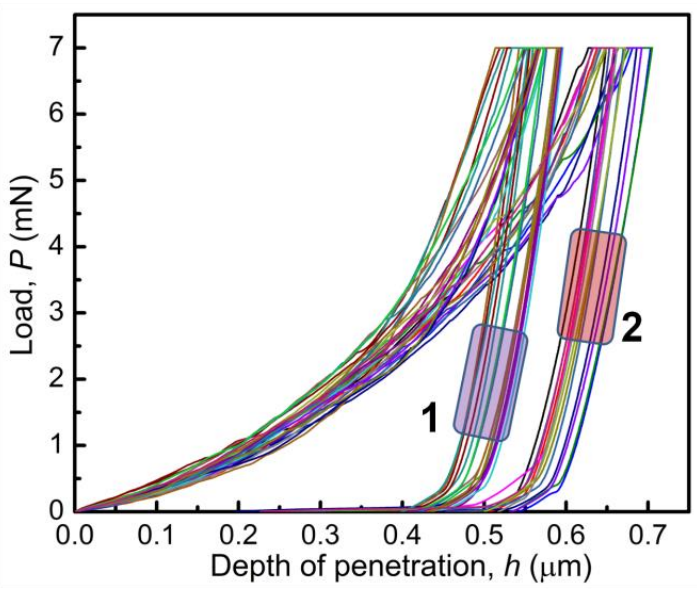

(a)

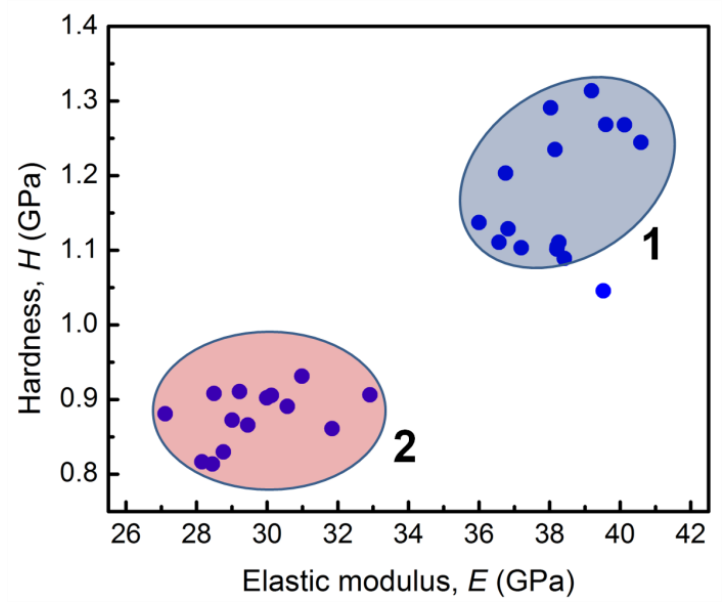

(b)

Fig. 2. Load vs. displacement $(P-h)$ curves (a) and plot of hardness $(H) v s$. elastic modulus $(E)$ of sodium saccharin dihydrate crystals (b) obtained with indentation normal to the (001) face

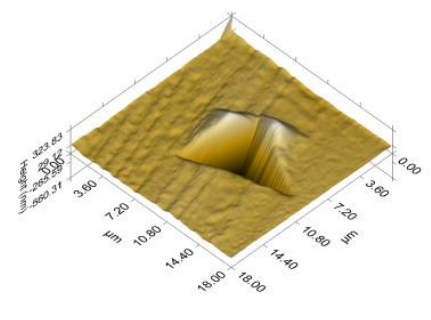

$2(001)$

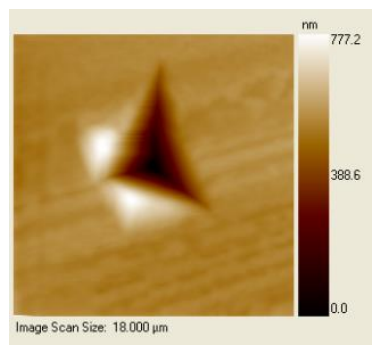

$1(001)$

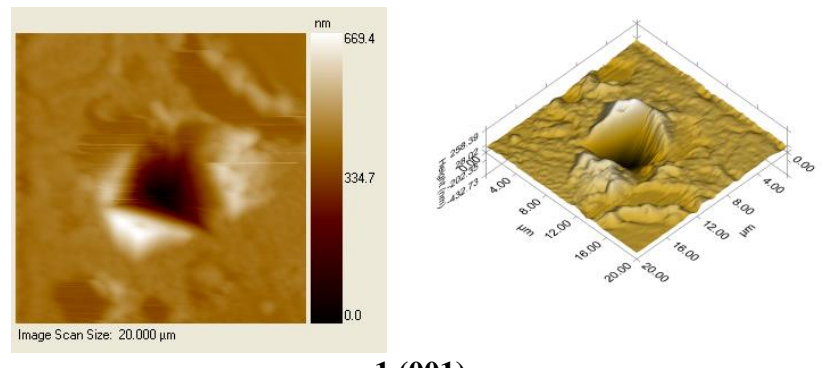

Fig. 3. AFM images of indent obtained on (001) after indentation 
Table 1

Elastic modulus $(E)$ and hardness $(H)$ values obtained for the (001) face of sodium saccharin dihydrate crystals

\begin{tabular}{ccc}
\hline \hline & $E(\mathrm{GPa})$ & $H(\mathrm{GPa})$ \\
\hline $\mathbf{1}(\mathbf{0 0 1})$ & $38.75 \pm 0.85$ & $1.20 \pm 0.04$ \\
$\mathbf{2 ( 0 0 1 )}$ & $25.68 \pm 0.72$ & $0.78 \pm 0.03$ \\
$\mathbf{( 0 1 1 )}$ & $18.40 \pm 0.063$ & $0.6620 \pm 0.022$ \\
$\mathbf{( 1 0 1 )}$ & $15.88 \pm 0.057$ & $0.7164 \pm 0.028$ \\
\hline \hline
\end{tabular}

Banerjee et al. refer it to as the JovanovskiKamenar hydrate (JK hydrate) [30]. Then, it is possible that the two domains with different mechanical response correspond respectively to regions of the original dihydrate and the JK hydrate. However, if this were the case, one should also have obtained a bimodal response upon nanoindentation of the other faces such as (011) and (101), especially the former. This was not noted by Kiran et al. [2] in their study and the responses are strictly unimodal in their case. The second possibility for the structural heterogeneity could be the regular and irregular regions in the structure, as hypothesized in the introductory section of this paper. A major drawback of this hypothesis is that the domain sizes of each of these regions as viewed on (001) are approximately $18 \times 14 \AA^{2}$, whereas indentation sizes, at $\sim 10 \times 10 \mu \mathrm{m}^{2}$, are much larger. Therefore, the domain sizes must be larger than, or at least comparable to, the nanoindentation dimensions for the observation of the bimodal response of the type we observe here. While it is difficult to draw firmer conclusions, it is possible that the reported crystal structure, which by definition is a space averaged structure, is not a really accurate representation at lower length scales and that the regular and irregular regions cover much larger domains than would seem to be the case by inspection of the crystal unit cell. In support of such a view, Banerjee et al. [22] had noted that the molecular positions and dimensions in the irregular regions vary from crystal to crystal. It is possible therefore that the real structure consists of regular and irregular regions, each of dimensions of at least several tens of $\mu \mathrm{m}$. In other words, some unit cells are fully regular while others are completely irregular. This does not explain the fact that the crystallographic refinement of atoms in the regular region proceeds well for the dihydrate [22].

\section{CONCLUSIONS}

Nanoindentation is a technique that allows the researcher to explore length scales that are smaller than in crystallography. Accordingly, struc- tural results obtained with these two techniques may be indicative of differences in these distance scales. Other sophisticated techniques like microIR, micro-Raman spectroscopy and micro-X-ray diffraction can be applied to analyze the depth of the bimodal response obtained from the nanoindentation experiment. Clearly, more work is required to shed light on this fascinating solid, sodium saccharin hydrate.

Acknowledgements. M.K.M. thanks CSIR for a Senior Research Fellowship. G.R.D. and U.R thank the Department of Science and Technology, India, for J. C. Bose Fellowships.

\section{REFERENCES}

[1] S. Varughese, M. S. R. N. Kiran, U. Ramamurty, G. R. Desiraju, Nanoindentation in crystal engineering: Quantifying mechanical properties of molecular crystals, $A n$ gew. Chem. Int. Ed., 52, 2701-2712 (2013).

[2] M. S. R. N. Kiran, S. Varughese, U. Ramamurty, G. R. Desiraju, Effect of dehydration on the mechanical properties of sodium saccharin dihydrate with nanoindentation, CrystEngComm., 14, 2489-2493 (2012).

[3] S. Varughese, M. S. R. N. Kiran, K. A. Solanko, A. D. Bond, U. Ramamurty, G. R. Desiraju, Interaction anisotropy and shear instability of aspirin polymorphs established by nanoindentation, Chem. Sci., 2, 2236-2242 (2011).

[4] C. Karunatilaka, D. K. Bučar, L. R. Ditzler, T. Friščić, D. C. Swenson, L. R. MacGillivray, A. V. Tivanski, Softening and hardening of macro- and nano-sized organic cocrystals in a single-crystal transformation, Angew. Chem. Int. Ed., 50, 8642-8646 (2011).

[5] M. K. Mishra, S. Varughese, U. Ramamurty, G. R. Desiraju, Odd-even effect in the elastic modulii of $\alpha, \omega$-alkanedicarboxylic acids, J. Am. Chem. Soc., 135, 81218124 (2013).

[6] S. Ghosh, A. Mondal, M. S. R. N. Kiran, U. Ramamurty, C. M. Reddy, The role of weak interactions in the phase transition and distinct mechanical behavior of two structurally similar caffeine cocrystals polymorphs studied by nanoindentation, Cryst. Growth Des., 13, 4435-4441 (2013).

[7] S. C. Sahoo, S. B. Sinha, M. S. R. N. Kiran, U. Ramamurty, A. F. Dericioglu, C. M. Reddy, P. Naumov, Kinematic and mechanical profile of the self-actuation of thermosalient crystal twins of 1,2,4,5-tetrabromobenzene: A molecular crystalline analogue of a bimetallic strip, J. Am. Chem. Soc., 135, 13843-13850 (2013).

[8] M. K. Mishra, G. R. Desiraju, U. Ramamurty, A. D. Bond, Studying microstructure in molecular crystals with nanoindentation: Intergrowth polymorphism in Felodipine, Angew. Chem. Int. Ed., 53, 13102-13105 (2014).

[9] G. Kaupp, M. R. Naimi-Jamal, Mechanically induced molecular migrations in molecular crystals, CrystEngComm., 7, 402-410 (2005).

[10] C. M. Reddy, G. R. Krishna, S. Ghosh, Mechanical properties of molecular crystals - applications to crystal engineering, CrystEngComm., 12, 2296-2314 (2010). 
[11] U. Ramamurty, J. Jang, Nanoindentation for probing the mechanical behavior of molecular crystals-a review of the technique and how to use it, CrystEngComm., 16, 12-23 (2014).

[12] S. Ghosh, M. K. Mishra, S. B. Kadambi, U. Ramamurty, G. R. Desiraju, Designing elastic organic crystals: Highly flexible polyhalogenated N-benzylideneanilines, $\mathrm{An}$ gew. Chem. Int. Ed., 54, 2674-2678 (2015).

[13] G. R. Desiraju, Crystal Engineering. The Design of Organic Solids; Elsevier: Amsterdam, 1989.

[14] G. R. Desiraju, J. J. Vittal, A. Ramanan, Crystal Engineering - A Text Book, World Scientific, 2011.

[15] G. R. Desiraju, Crystal engineering: A holistic view, Angew. Chem. Int. Ed., 46, 8342-8356 (2007).

[16] G. R. Desiraju, Crystal engineering: From molecule to crystal, J. Am. Chem. Soc., 135, 9952-9967 (2013).

[17] C. Fahlberg, I. Remsen, Ueber die Oxydation des Orthotoluolsulfamids, Ber. Dtsch. Chem. Ges., 12, 469473 (1879)

[18] M. H. Defournel, Metallic "saccharinates", Bull. Soc. Chim. Fr., 25, 322-329 (1901).

[19] P. Naumov, G. Jovanovski, S. Abbrent, L. Tergenius, Thermal behavior of the saccharinates of $\mathrm{K}^{+}, \mathrm{Na}^{+}, \mathrm{Rb}^{+}$, $\mathrm{Cs}^{+}$and $\mathrm{NH}_{4}^{+}$: structural inferences, Thermo-chim. Acta, 359, 123-130 (2000).

[20] G. Jovanovski, O. Grupče, B. Šoptrajanov, The O-H and O-D stretching vibrations in the hydrates of sodium and potassium saccharinate: spectra-structure correlations, $J$. Mol. Struct., 219, 61-66 (1990).

[21] P. Naumov, G. Jovanovski, O. Grupče, B. Kaitner, A. D. Rae, S. W. Ng, Solid-state structure and temperature/evacuation-induced dehydration of sodium saccharinate 1.875 hydrate, Angew. Chem. Int. Ed., 44, 1251-1254 (2005).
[22] R. Banerjee, P. M. Bhatt, M. T. Kirchner, G. R. Desiraju, Structural studies of the system $\mathrm{Na}$ (saccharinate) $\cdot \mathrm{nH}_{2} \mathrm{O}$ : a model for crystallization, Angew. Chem. Int. Ed., 44, 2515-2520 (2005).

[23] W. C Oliver, G. M. Pharr, An improved technique for determining hardness and elastic modulus using load and displacement sensing indentation experiments, $J$. Mater. Res., 7, 1564-1583 (1992).

[24] W. C. Oliver, G. M. Pharr, Measurement of hardness and elastic modulus by instrumented indentation: Advances in understanding and refinements to methodology, J. Mater. Res., 19, 3-20 (2004).

[25] N. Blagden, R. J. Davey, Polymorph Selection: Challenges for the Future, Cryst. Growth Des., 3, 873-885 (2003).

[26] R. Dubey, M. S. Pavan, G. R. Desiraju, Structural landscape of benzoic acid: using experimental crystal structures of fluorobenzoic acids as a probe, Chem. Commun., 48, 9020-9022 (2012).

[27] R. Dubey, M. S. Pavan, T. N. G. Row, G. R. Desiraju, Crystal landscape in the orcinol:4,4'-bipyridine system: synthon modularity, polymorphism and transferability of multipole charge density parameters, IUCrJ, 1, 8-18 (2014).

[28] R. Dubey, G. R. Desiraju, Combinatorial Crystal Synthesis: Structural Landscape of Phloroglucinol:1,2-bis(4pyridyl)ethylene and Phloroglucinol:Phenazine, Angew. Chem. Int. Ed., 48, 13178-13182 (2014).

[29] R. Dubey, G. R. Desiraju, Exploring the crystal structure landscape with a heterosynthon module: Fluorobenzoic acid: 1, 2-bis (4-pyridyl) ethylene 2: 1 cocrystals, Cryst. Growth Des., DOI: 10.1021/cg501553m (2014).

[30] G. Jovanovski, B. Kamenar, Two ionic saccharinates: (1a) sodium saccharinate $2 / 3$ hydrate, $\mathrm{C}_{7} \mathrm{H}_{4} \mathrm{NO}_{3} \mathrm{SNa} .2 / 3 \mathrm{H}_{2} \mathrm{O}$; (1b) magnesium disaccharinate heptahydrate, $\left(\mathrm{C}_{7} \mathrm{H}_{4} \mathrm{NO}_{3} \mathrm{~S}\right)_{2} \mathrm{Mg} .7 \mathrm{H}_{2} \mathrm{O}$, Cryst. Struct. Commun., 11, 247-255 (1982). 
